\title{
TECTONIC CONTROL ON THE COASTAL ZONE GEOMORPHOLOGY OF THE NORTHEASTERN PARÁ STATE
}

\section{PEDRO WALFIR MARTINS E SOUZA FILHO}

\begin{abstract}
Based on the integration of geomorphologic, geophysical and structural data it was possible to characterize the large-scale distribution of the Quaternary sedimentary environments on the northeastern Para coastal zone. Two geomorphological sectors are observed in the study area: sector 1, between Marajo and Pirabas Bay, presents a narrow, no more than $2 \mathrm{~km}$ wide coastal zone, developed over the Pard platform, and seems to be a very stable area. In sector 2, from Pirabas Bay eastward, the coastal zone becomes broader, almost $30 \mathrm{~km}$ wide, from inactive coastal cliffs to the shoreline. The evolution of this sector is related to the Bragança-Viseu coastal basin, which is controlled by normal faults that reach the present coastal zone. Therefore, the northeastern Para coastal zone presents a stable coast associated to the Para platform, and a submerging coast related to the Braganfa-Viseu coastal basin.
\end{abstract}

Keywords: Coastal zone, geomorphology, tectonic control, gravity data, remote sensing, Northern Brazil.

INTRODUCTION The continental margin of northern Brazil has been studied to trace mid-ocean tectonic structures into the continental margins and into the continental interior (Gorini and Bryan 1976). Works discussing the geology and geomorphology at Atlantic type margins have emphasized the tectonic, stratigraphic, sedimentary and morphologic control of northern Brazilian passive margin evolution (Zembruscki et al. 1972, Campos et al. 1974, Asmus 1984). However, the coastal zone is an integral part of the continental margin, and its long-term evolution is controlled by thermo-tectonic evolution of passive margins (Gilchrist and Summerfield 1994).

The coastal zone evolution in Brazil has been traditionally studied with basis on sea level changes, sedimentary dynamics and landform features. However, the large-scale geomorphology of the northern Brazilian coastal zone is directly related to the structural and sedimentary evolution of the coastal basins. This area is clearly linked to the basement framework and to the tectonism that affected this basin and is related to the upflit and collapse that preceded the opening of the Equatorial Atlantic ocean (Aranha et al. 1990). The purpose of the present paper is to evince the tectonic control of coastal zone evolution with basis on the integration of geomorphologic, geophysical and structural data.

GEOLOGIC SETTING The general tectonic configuration of the northern Brazilian continental margins was established in the Early Cretaceous, during the opening of the Equatorial Atlantic Ocean (Rezende and Ferradaes 1971, Campos et al. 1974, Asmus 1984). Campos et al. (1974) noted that Precambrian lines of crustal weakness were reactived by tensional forces responsible for gravity-faults (rifts) and coastal basins depressed in the basement. These faults show a stepped pattern from the continent to the ocean, forming a series of horsts and grabens (Gorini and Bryan 1976, Igreja 1992). According to Suguio and Martin (1996), the role of marginal basins, as a neotectonic agent in the evolution of the Brazilian coast, must be considered. Thus, the geotectonic activity in northeastern of Pará is controlled by E-W transcurrent faults connected by NW-SE normal faults, whereas the structural and sedimentary evolution of the area is clearly linked to the reactivation of the basement (Costa et al. 1996).

Along the northeastern Para coast, two structural frameworks can be observed (Fig. 1): the Pará platform and the Braganca-Viseu basin (Gorini and Bryan 1976). The origin and evolution of these tectonic structures are explained by a model of Atlantic-type margins (Asmus 1984).

During the Quaternary, the northeastern Pard coastal zone has been affected by regressive and transgressive episodes. Milliman and Barreto (1975) dated lagoon oolites at 17,400 years BP, which suggests that the continental shelf was exposed and sea level was located on the shelf break ( -80 to $-90 \mathrm{~m}$ lower than present sea level). Milliman and Emery (1968) believe that from 17.400 years BP, the sea level began to rise and coastline and transgressive sandy sheets migrated landward, eroding and onlapping the coastal plateaus to form active cliffs. Afterwards, under stillstand, or slower relative sea level rise, it is possible to observe a muddy progradation of the coastline seaward that marks the beginning of intertidal mangrove development. (Silva 1996, Souza Filho and El-Robrini 1996, Souza Filho and El-

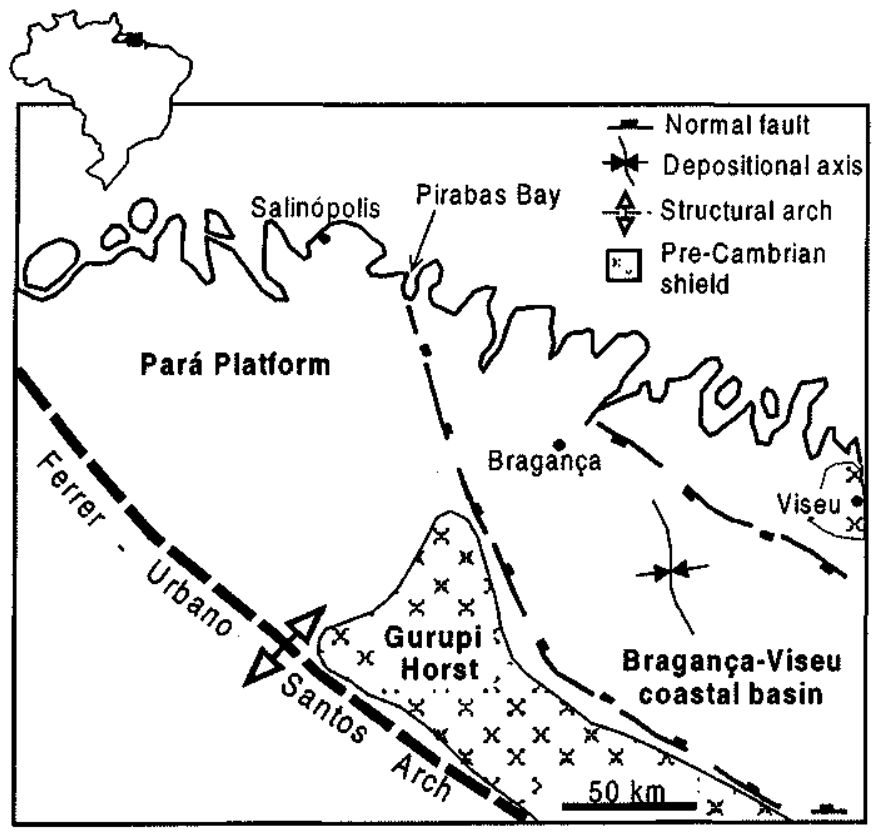

Figure I - Localization and tectonic map of northeastern Para State showing two geologic sectors in the coastal zone (based on Gorini and Bryan 1976).

Robrini 1998). This sea level history has strongly controlled the Quaternary evolution of the coastal zone, which is characterized now by wide mudflat environments (mangroves).

DAT SET AND METHODS Digital data of TM Landsat-5 imageries in orbit-point 222-61 and 223-60 were selected to cover the northeastern Para coastal zone. The images were not geocoded to make the false color composition on a 1:250,000 scale. Details of the satellite data used are given on Table 1. Auxiliary data such as plan-altimeter maps on a 1:250,000 scale, geological map on a 1:50,000 scale, bathymetric and sedimentological maps on a 1:5,000,000 scale and field observation were used for the study.

The geomorphologic study of the coastal zone was based on interpretation of TM Landsat-5 satellite data in the form of false color composite (4R5G3B). Digitally enhanced products were carried out using standard keys such as tone/color, texture, patterns, form, size,

Table I-Details of used satellite data

\begin{tabular}{|c|c|c|c|}
\hline $\begin{array}{c}\text { Platform/ } \\
\text { Sensor }\end{array}$ & $\begin{array}{c}\text { Orbit/ } \\
\text { Point }\end{array}$ & $\begin{array}{c}\text { Acquisition } \\
\text { date }\end{array}$ & $\begin{array}{c}\text { Spatial } \\
\text { resolution }\end{array}$ \\
\hline Landsat TM 5 & $222 / 61$ & August 24, 1985 & $30 \times 30 \mathrm{~m}$ \\
\hline Landsat TM 5 & $223 / 60$ & July 24, 1988 & $30 \times 30 \mathrm{~m}$ \\
\hline
\end{tabular}


shape and drainage. The accuracy of interpretation was also assessed through fieldwork. The geomorphologic map was integrated with gravity and tectonic maps to establish the relationships between coastal zone geomorphology and the tectonic framework of the northern Brazilian continental margin.

DIFFERENT GEOLOGIC SECTORS OF THE NORTHEASTERN PARA COASTAL ZONE Along the Para continental margin, two geologic sectors can be observed, according to Gorini and Bryan (1976). The Para platform as defined by Rezende and Ferradaes (1971), constitutes areas of no more than 2,000 m of Cretaceous or Jurassic/Triassic deposits. The Tertiary sedimentary cover, almost $1,500 \mathrm{~m}$ thick, is not tectonically influenced by older centers of deposition, which reflects great tectonic stability compared to adjoining coastal basins (Rezende and Ferradaes 1971, Gorini and Bryan 1976). The other sector is represented by the Braganca-Viseu coastal basin that constitutes a graben bounded by normal faults along the northwest-southeast structural trend. Sedimentary thickness reaches almost 4,500 m, deposited in two mega-sequences: CodoGrajaú sequence (Late Aptian) and Itapecuru sequence (Early Albian to Early Cenomanian) (Aranha et al. 1990). The Cenozoic sequence is constituted by the Pirabas Formation, deposited under transgressive conditions, responsible for a carbonatic sedimentation, followed by Barreiras Group deposition under regressive conditions (Goes et al. 1990). Nowadays, the Barreiras Group forms coastal plateaus along the coast.

These geological sectors are controlled by the tectonic of the Pará continental margin (Fig. 1). The Para platform goes from Marajó to Pirabas Bay and constitutes the tectonic boundary of the continental margin. This platform represents a gravimetric high; easily identified on the Bouguer gravity anomaly map (Fig. 2), which can explain the narrow geomorphologic expression of the coastal plain. The BragançaViseu coastal basin is completely developed in land and this geologic sector represents a gravimetric low developed from the Pirabas Bay to Gurupi River along a northwest-southeast direction and from coastline to continental fracture zone (Gurupi horst) in a northeast-southwest direction (Fig. 2). According to Aranha et al (1990) and Igreja (1992), this basin is submitted to transtensive movimentation predominantly dextral, due to the displacement of the South American and African plates. Therefore, the coastal zone is located in a different geologic sector in relation to continental shelf, developed over the Para platform.

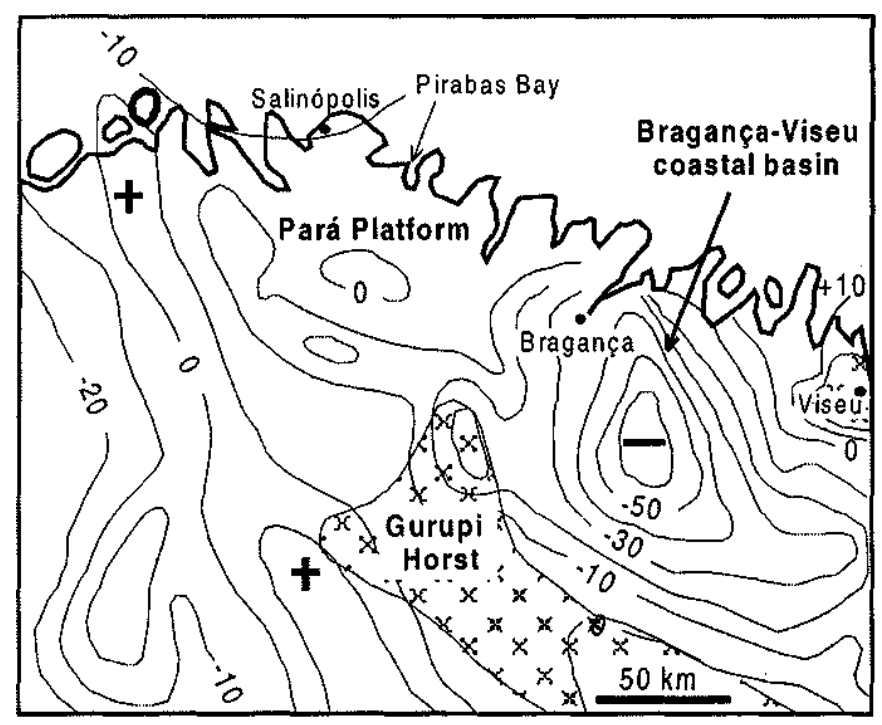

Figure 2 - Bouguer gravity anomaly map of northeastern Para State (Oliveira and Castro 1971).

COASTAL ZONE GEOMORPHOLOGY AND TECTONIC FRAMEWORK Stretching out for $300 \mathrm{~km}$, the northeastern Pará littoral constitutes a submergence coast subdivided in two sectors (Franzinelli (1992). Sector 1 extends from Marajo Bay to Pirabas Bay, where the bays cut the active cliffs. Sector 2 extends from Pirabas Bay eastward, where the coastal plateaus stretch out southward and sustain inactive cliffs. These compartments are visible in TM images. The coastal sedimentary environments (predominantly mangroves) widen considerably towards the east from Pirabas Bay (Fig. 3). As the coastal plateaus extend southward, the coastal zone is wider and consequently this sector presents a lower topography, much more influenced by floods and tides.

The two geomorphologic sectors recognized by Franzinelli (1992) in the northeastern coast of Pará can be described as morphostructural compartments. Sector 1 presents a narrow, no more than $2 \mathrm{~km}$ wide coastal zone, developed over Barreiras Group sediments, that reach the littoral as active coastal cliffs. The cliffs constitute the outer boundary of the coastal plateaus exposed to erosion along the shoreline due to waves and tides. Estuaries incised in the plateaus extend for more than $70 \mathrm{~km}$ landward and mangrove deposits constitute the mud intertidal flat (Fig. 3A). In Sector 2, the coastal zone is broader, up to almost 30 $\mathrm{km}$ wide from inactive coastal cliffs to the shoreline (Fig. 3B). The inactive cliffs are $1 \mathrm{~m}$ high in direct contact with the mud tidal flat represented by mangrove prograding environment and the estuaries extend for more than $100 \mathrm{~km}$ from shoreline to coastal plateaus.

DISCUSSION Based on integration of these data it is possible to state that sea level changes only could not explain the differences in sedimentary pattern and geomorphologic compartimentation between the western and eastern part of northeastern Para State. In the sector 1, on the Para platform, the higher relief developed in Tertiary deposits is found near the coastline forming active cliffs. Based on gravity map, this sector is found to be subject to stability or emergence processes. In the sector 2, in the Braganca-Viseu coastal basin, the relief along the coastline is lower and developed in Quaternary unconsolidated deposits. Gravity map analysis shows that this sector represents a submerging coast, where the sediment supply has been more important to build the coastal zone than in sector 1, since the Braganga-Viseu basin represents a sink of sediments.

It is worth mention that the transition between emergent and submergence zones is abrupt, which can be observed in the gravity maps as in TM images. This seems to eliminate the hypothesis of morphological differentiation due to a continental flexure described in other sectors of the Brazilian coastline (Suguio and Martin 1976, Driscoll and Karner 1994, Bittencourt et al. 1999). Therefore, the tectonic interactions between fault blocks, separated by NW-SE normal faults, are due to the tectonic activity during the Equatorial Atlantic Ocean opening, persisting active during the Quaternary.

Sediment distribution along the coastal zone is also controlled by tectonic evolution of the continental margin. In the sector 1 , the coastal plain is developed in the tidal flat along estuaries limited by Tertiary deposits (Fig. 3A) that reach the coastline. In the sector 2, inactive cliffs mark the interior limit of the Quaternary plain; which possibly represents an ancient reactivated fault. From inactive cliffs, the Quaternary deposits prograde almost $30 \mathrm{~km}$ seaward (Fig. 3B), probably due to continuous submergence of the coast during the Holocene.

In low elevation passive margins, such as in northeastern Pará, a broad continental shelf leads to a coastal plain, which rises gradually to a relatively low-lying interior surface (Gilchrist and Summerfield 1994). The continental shelf of the Para is $220 \mathrm{~km}$ wide, with a smooth and gentle bathymetric surface, forming broad terraces (Zembruski et al. 1972). The morphology the continental shelf must be responsible for the control of the coastal plain morphology. However, two geomorphological sectors can be observed showing several different characteristics. Therefore, differences in the continental structures are reflected in the Quaternary coastal deposit distribution that is controlled by the tectonic framework.

\section{SUMMARY AND CONCLUSIONS}

The large-scale geomorphological evolution of northeastern Pará State is controlled by the tectonic setting of the passive margin developed since the Early Cretaceous during the opening of the Equatorial Atlantic Ocean. Two geomorphological sectors are observed in the study area. One is developed on the Para platform, and shows a wide Tertiary sedimentary cover represented by the Pirabas Formation and the Barreiras Group. The evolution of this sector is not tectonically influenced by older centers of deposition, seeming to be very stable (Rezende and Ferradaes 1971). The coastal deposits are restrict to estuarine channels, 

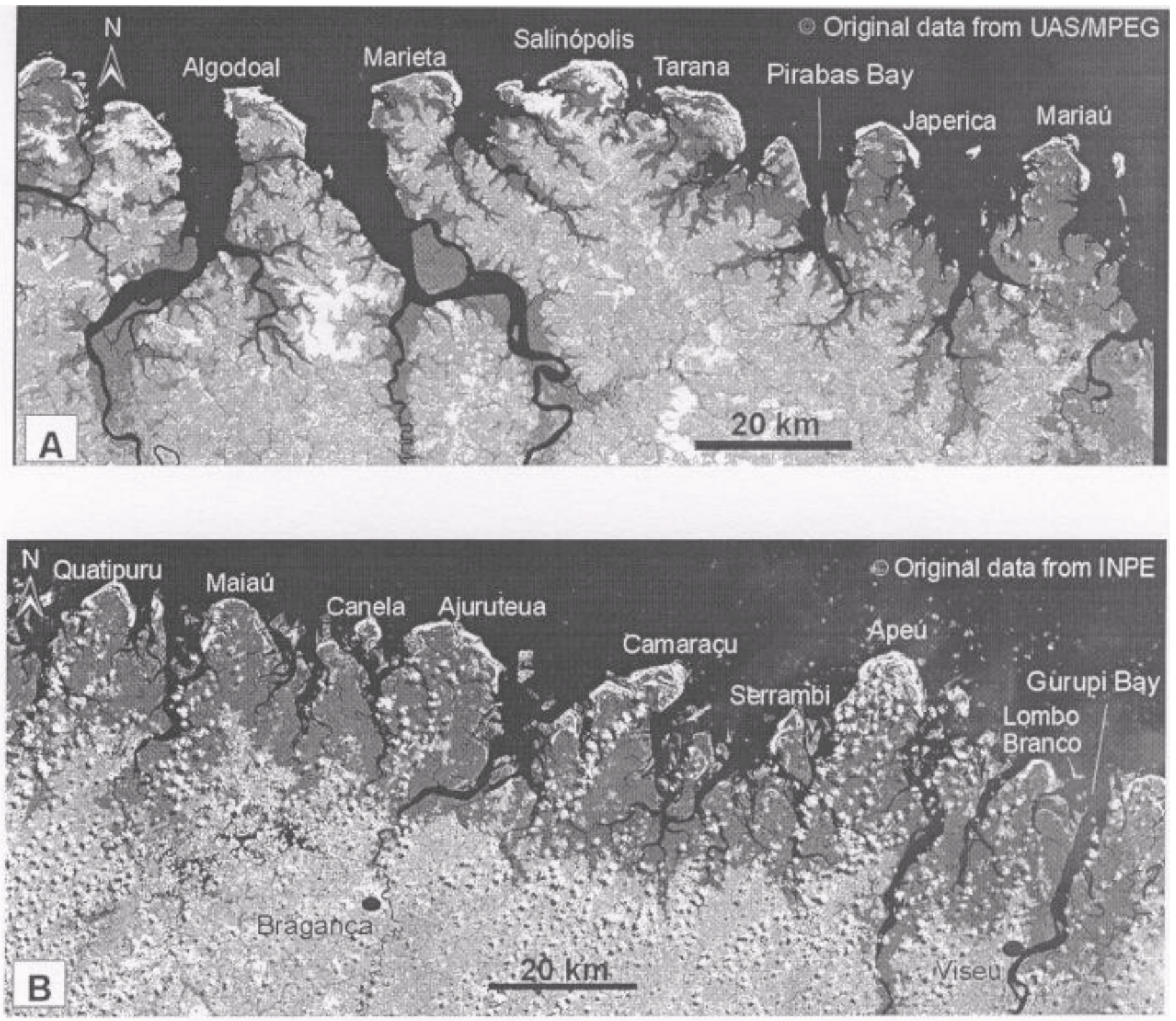

Figure 3 - Band 5 of TM Landsat imagery showing the coastal geomorphology of the northeastern Pará State. A) In the sector I, note that coastal plateaus reach the shoreline and coastal plain is narrow. B) In the sector 2, observe that coastal plateaus stretch out southward to constitute inactive cliffs and coastal plain becomes wide, reaching more than $30 \mathrm{~km}$ of width.

prograding no more than $2 \mathrm{~km}$ seaward, consisting of an emerging coast. Sector 2 has an evolution related to the Bragança-Viseu coastal basin that is controlled by normal faults that reach the present coastal zone. The structural framework of this coastal basin is responsible for a submerging coastal zone, showing a wide mangrove ecosystem due to mudflat progradation.

The tectonic control of the coastal zone geomorphology has affected long-term and large-scale landscape development. Therefore, the tectonic framework of the Equatorial Atlantic margin controls large-scale geomorphic characteristics of the Quaternary sedimentary environments.

Acknowledgement To the Remote Sensing Division of the National Institute of Spatial Research (DSR-INPE) and the Spatial Analysis Unit of the Museu Paraense Emflio Goeldi (UAS-MPEG) for providing digital data ofTM Landsat imageries; to the Geoscience Center of the Federal University of Para (CPGG-UFPA) for field support; to Dr. Maamar El-Robrini for laboratory support; Dra. Carmem Pires Frazão for reviewing the English, to CAPES for a Ph.D. scholarship, and to two anonymous referees of RBG for their critical review of the manuscript.

\section{References}

Aranha L. G. F., Lima H. P., Souza J. M. P., Makino R. K. 1990. Origem e evolução das bacias de Bragança-Viseu, São Liris e Ilha Nova. In: De Raja Gabaglia G. P. and Milani E. J. (ed.). Origem e evolucão de bacias sedimentares. Rio de Janeiro, PETROBRAS, 221-233.

Asmus H. E. 1984. Geologia da margem continental brasileira. In: Schobbenhaus G. (ed.) Geologia do Brazil, Rio de Janeiro, DNPM, 443-472.

Bittencourt A. C. S. P., Dominguez J. M. L., Ussami N. 1999. Flexure as a tectonic contro on the large scale geomorphic characteristics of the eastern Brazil coastal zone. Journal of Coaxial Research, 15(2):505-519.
Campos C. W. M., Ponte F. C., Miura K. 1974. Geology of the Brazilian continental margin. In: Burk, C. A. and Drake, C. L. (eds.). The geology of continental margins. Berlin, Springer-Verlag, 447-461.

Costa J. B. S., Bemerguy R. L., Hasui, Y, Borges M. S., Ferreira Jr. C. R. P., Bezerra P. E. L., Costa M. L. C., Fernandas J. M. G. 1996. Neotectonica da Região Amazônica: aspectos tectonicos, geomorfologicos e deposicionais. Geonomos, 4(2):23-44.

Driscoll N. W. and Karner G. D. 1994. Flexural deformation due to Amazon fan loading: a feedback mechanism affecting sediment delivery to margins. Geology, 22:1015-1018. 
Franzinelli E. 1992. Evolution of the geomorphology of the coast of the State of Para, Brazil. In: M. T. Prost (ed.). Evolution des littoraux de Guyane et de la Zone Caraibe Meridionale pendant le Quaternaire. Paris, ORSTOM, 203-230.

Gilchrist A. R. and Summerfield M. A. 1994. Tectonic models of passive margins evolution and their implications for theories of long-term landscape development. In: Kirkby M. J. (ed.). Processes models and theoretical geomorphology. Chilchester, Willey,
55-84.

Goes A. M., Rossetti D. F, Nogueira A. C. R., Toledo P. M. 1990. Modelo deposicional preliminar da Formafao Pirabas no nordeste do Estado do Para. Boletim do Museu preiminar Emilia Goeldi. Serie Ciencias da Terra, 2:3-15.

Paraense Emilia Goeldi, Serie Ciencias da Terra, 2:3-15.
Gorini M. A. and Bryan G. M. The tectonic fabric of the Equatorial Atlantic and adjoining continental margins: Gulf of Guinea to northeastern Brazil. Anais da Academia Bra-

sileira de Ciências, 48 (suplemento):101-119.

Igreja H. L. S. 1992. Aspectos tectonos-sedimentares do Fanerozoico do nordeste do Pará e noroeste do Maranhão, Brasil. Centra de Geociências, Universidade Federal do Pará. Belem, Tese de Doutoramento, $191 \mathrm{p}$.

Milliman J.D. and Barreto H.T. 1975. Relict magnesian calcite oolite and subsidence of Amazon Shelf.. Sedimentology, 22:137-145.

Milliman J.D. and Emery K.O. 1968. Sea levels during the past 35.000 years. Science, 162:1121-1123.

Oliveira E. and Castro P. J. M. 1971. Problemas de integração gravimetrica no Brasil. In SBG, Congresso Brasileiro de Geologia, 25, São Paulo, Anais, 2:71-78.

Pontes F. C. and Asmus H. E. 1976. The Brazilian marginal basisn: current state of knowledge. Anais da Academia Brasileira de Ciências, 48 (suplemento):215-235.
Rezende W. M. and Ferradaes J. O. 1971. Integração geologica regional da bacia sedimentar da Foz do Rio Amazonas. In: SBG, Congresso Brasileiro de Geologia, 25, São Paulo, Anais, 3:203-214

Silva M. S. 1996. Morfoestratigrafia e evolucão holocenica da Planicie Costeira de Salinopolis, Nordeste do Estado do Pará. Centre de Geociências, Universidade Federal do Para. Belém, Dissertação de Mestrado, 142p.

Souza Filho R W. M. and El-Robrini M. 1996. Morfologia, processes de sedimentacão e itofacies dos ambientes morfosedimentares da Planicie Costeira Bragantina - Nordeste do Pard (Brasil). Geonomos, 4:1-16.

Souza Filho P.W.M. and El-Robrini M. 1998. As variances do nivel do mar e a estratigrafia de sequencias da Planicie Costeira Bragantina - Nordeste do Para, Brasil. Boletim do Museu Paraense Emilia Goeldi, Serie Ciencias da Terra, 10:45-78.

Suguio K. and Martin L. 1976. Brazilian coastline Quaternary formations - The states of São Paulo and Bahia littoral zone evolution schemes. Anais da Academia Brasileira de Ciencias 48 (suplemento):325-334. [

Suguio K. and Martin L. 1996. The role of neotectonics in the evolution of the Brazilian coast Geonomos, 4(2):45-53.

Zembruscki S. G., Barreto H. T., Palma J. C., Milliman J. D. 1972. Estudo preliminar das provfncias geomorfologicas da margem continental brasileira. In: SBG, Congresso Brasileiro de Geologia, 26, Bel6m, Anais, 2:187-209.

Contribution IGC-190

Received March 13,2000

Accepted for publication April 28, 2000 